\title{
The dishomeostasis of metal ions plays an important role for the cognitive impartment
}

\author{
Dehua Chui ${ }^{1,3^{*}}$, Huan Yang ${ }^{1}$, Hecheng Wang ${ }^{1}$, Tuo $\mathrm{Jl}^{1}$, Jia Yu ${ }^{1,2}$, Shouzi Zhang ${ }^{2}$, Zheng Chen², WeiZhong Xiao ${ }^{3}$ \\ From Molecular Neurodegeneration: Basic biology and disease pathways \\ Cannes, France. 10-12 September 2013
}

Profound synapse loss is one of the major pathological hallmarks associated with Alzheimer's disease (AD) and might underlie memory impairment. The homeostasis of metal ions plays an important role in health and neurodegenerative disease by influencing cellular biochemical pathways. The disturbance of some metal ions may have cytotoxic effects, which may cause cell death leading to neurodegenerative disorders such as AD. The aim of the present study was to investigate metal concentrations in whole blood from Chinese AD patients with APOE $\varepsilon 4$ allele carrier. Concentrations of metals (magnesium, calcium, manganese, iron, cobalt, copper, zinc, selenium, cadmium, mercury and lead) were determined in whole blood by inductively coupled plasma mass spectrometry (ICPMS) in 40 Chinese people with different Mini-mental state examination (MMSE) score. Normal APP processing could be restored when magnesium was adjusted back to physiological concentration. Our findings suggest that supplementation of magnesium has a therapeutic potential for preventing AD. We observed that Plasma Mg, Zn and Se levels were found to be significantly lower in patients with AD compared with controls. Furthermore, there is a significant negative correlation between manganese and MMSE score. Whereas other metal ions have no association with MMSE score. These result suggests that dishomeostasis of metal ions may involve in the progress of $\mathrm{AD}$ pathology, and elevation of brain magnesium exerts substantial synaptoprotective effects in a mouse model of $\mathrm{AD}$ and may have therapeutic potential for treating $\mathrm{AD}$ in humans.

\section{Acknowledgements}

This work was supported by 973 Program No.2012CB911004 and the NSFC Grants No.No.81171015.

${ }^{1}$ Neuroscience Research Institute, Health Science Center, Peking University, Beijing, China

Full list of author information is available at the end of the article

\section{Authors' details}

'Neuroscience Research Institute, Health Science Center, Peking University, Beijing, China. ${ }^{2}$ Beijing Geriatric Hospital, Beijing, China. ${ }^{3}$ Department of Neurology, Peking University Third Hospital, Beijing, China.

Published: 13 September 2013

\section{References}

1. Jia Yu, Miao Sun, Zheng Chen, Jiangyang Lu, Yi Liu, Liang Zhou, Xuemin Xu, Dongsheng Fan, Chui DH: Magnesium modulates amyloid precursor protein trafficking and processing. J Alzheimers Dis 2010, 20(4):1091-1106.

2. Li W, Yu J, Liu Y, Huang X, Abumaria N, Zhu Y, Huang X, Xiong W, Ren C, Liu XG, Chui DH, Liu G: Elevation of brain magnesium prevents and reverses cognitive deficits and synaptic loss in Alzheimer's disease mouse model. J Neurosci 2013, 33(19):8423-8441.

3. Chui DH, et al: . Magnesium in the Central Nervous System. Chapter 18, Magnesium and Alzheimer's disease The University of Adelaide Press;9780987073051 2012, 239-250, Chapter DOl: http://dxdoi.org/10.1017/ UPO9780987073051.019.

\section{doi:10.1186/1750-1326-8-S1-P13}

Cite this article as: Chui et al:: The dishomeostasis of metal ions plays an important role for the cognitive impartment. Molecular

Neurodegeneration 2013 8(Suppl 1):P13.
Submit your next manuscript to BioMed Central and take full advantage of:

- Convenient online submission

- Thorough peer review

- No space constraints or color figure charges

- Immediate publication on acceptance

- Inclusion in PubMed, CAS, Scopus and Google Scholar

- Research which is freely available for redistribution
() Bïomed Central
C Biomed Central

(c) 2013 Chui et al; licensee BioMed Central Ltd. This is an Open Access article distributed under the terms of the Creative Commons Attribution License (http://creativecommons.org/licenses/by/2.0), which permits unrestricted use, distribution, and reproduction in any medium, provided the original work is properly cited. 